\title{
Partial diel vertical migration in an omnivorous macroinvertebrate, Mysis diluviana
}

\author{
Peter T. Euclide $\cdot$ Sture Hansson $\cdot$ Jason D. Stockwell
}

Received: 12 January 2016/Revised: 23 August 2016/Accepted: 6 September 2016/Published online: 16 September 2016 (C) The Author(s) 2016. This article is published with open access at Springerlink.com

\begin{abstract}
Partial migration, whereby only a portion of a population migrates, has just recently received attention in aquatic systems. Partial diel vertical migration (DVM) has received even less attention but could significantly influence our understanding of trophic interactions and nutrient movement in open water systems. Recent work in the Baltic Sea shows differences in isotope composition between benthic and pelagic Mysis salemaai sampled at night, suggesting that partial DVM may be fixed at the individual level. Historic observations of North American M. diluviana suggest partial DVM in this species, but this behavior has largely been ignored in the literature. We used length, occurrence of gravid females, and body $\delta^{13} \mathrm{C}, \delta^{15} \mathrm{~N}, \delta^{34} \mathrm{~S}$, and C: $\mathrm{N}$ ratio as
\end{abstract}

Handling editor: Karl E. Havens

Electronic supplementary material The online version of this article (doi:10.1007/s10750-016-2982-5) contains supplementary material, which is available to authorized users.

\section{P. T. Euclide · J. D. Stockwell ( $\square)$}

Rubenstein Ecosystem Science Laboratory, University of Vermont, 3 College Street, Burlington, VT 05401, USA e-mail: jason.stockwell@uvm.edu

P. T. Euclide

e-mail: peter.euclide@gmail.com

S. Hansson

Department of Ecology, Environment and Plant Sciences, Stockholm University, SE-106 91, Stockholm, Sweden e-mail: sture.hansson@su.se markers to test for differences among adult $M$. diluviana collected from benthic and pelagic habitats at night in Lake Champlain, USA. We found differences in body length and occurrence of gravid females between pelagic- and benthic-caught $M$. diluviana and differences in $\mathrm{C}: \mathrm{N}$ between pelagic- and benthiccaught non-gravid individuals, consistent with life stage and body condition hypotheses for partial migration. Partial DVM of $M$. diluviana could have significant impacts on population assessments which could bias food web models used in basic research and management.

Keywords Mysis diluviana $\cdot$ DVM $\cdot$ Partial migration $\cdot$ Isotope $\cdot$ Body condition

\section{Introduction}

Partial migration occurs when some individuals in a population migrate while others remain resident (Chapman et al., 2011). Although extensively studied in birds (Lundberg, 1988), partial migration has received less attention in aquatic systems (Chapman et al., 2012). Fish and macroinvertebrates exhibit partial horizontal (Brodersen et al., 2011) and diel vertical migrations (Brodersen et al., 2008; Mehner \& Kasprzak, 2011; Ogonowski et al., 2013), although examples are limited.

Diel vertical migration (DVM) in aquatic organisms has been hypothesized to be the largest 
synchronized movement of animal biomass in the world (Hays, 2003), transporting energy and nutrients vertically in the water column (Longhurst \& Harrison, 1988; Schnetzer \& Steinberg, 2002). Predator avoidance is a common explanation for DVM, enabling organisms to take advantage of food-rich surface waters at night, while limiting their vulnerability to visual predators during the day (Clark \& Levy, 1988; Lampert, 1989; Loose \& Dawidowicz, 1994). However, many other environmental factors such as light and temperature affect DVM behavior (Lampert, 1989; Pearre, 2003; Mehner, 2012), all of which could differentially impact individuals based on life stage or reproductive status and thus lead to variation in migration behavior among individuals within populations.

Mysis diluviana (Audzijonytė \& Väinölä, 2005) (hereafter Mysis when referring to this species) is a common macroinvertebrate in North America that exhibits pronounced DVM throughout its range (e.g., Beeton \& Bowers, 1982; Ahrenstorff et al., 2011). Mysis prefers cold $\left(<8^{\circ} \mathrm{C}\right)$ and deep $(>50 \mathrm{~m})$ lakes, typically exhibiting maximum densities in areas with bathymetric depths $>100 \mathrm{~m}$ (Carpenter et al., 1974; Kelly et al., 2011). Mysis is omnivorous and feeds on both benthic and pelagic food sources (Johannsson et al., 2001; Sierszen et al., 2011). Thus, Mysis is able to forage in benthic and pelagic environments with DVM providing an important benthic-pelagic link, transporting benthic-derived nutrients to pelagic environments and vice versa (Sierszen et al., 2011, 2014; Oliver et al., 2014).

Despite extensive documentation of and research on Mysis DVM (op. cit.) and its proximate cues such as light, temperature and predator density (Boscarino et al., 2009a, b, 2010), and historical observations of epibenthic mysids during nighttime (Morgan, 1980; Bowers, 1988), partial DVM in Mysis has received little attention. Morgan (1980) hypothesized that the sudden absence of gravid Mysis in pelagic tows in Lake Tahoe during November and December was the result of gravid Mysis occupying benthic habitat at night to reduce predation risk, consistent with the asset protection principle (Clark, 1994). Partial DVM may also reflect differences in fasting ability or body condition (body condition hypothesis) or hunger and satiation (hunger/satiation hypothesis) among individuals (Pearre, 2003; Chapman et al., 2011) where individuals only perform DVM when hungry. Finally,
Mysis could represent phenotypically different ecotypes, simplified as one migratory and one benthicresident population (c.f. Lundberg, 1987; Ogonowski et al., 2013).

Partial DVM in Mysis spp. in the Baltic Sea was described several decades ago (Rudstam et al., 1989) and more recently (Ogonowski et al., 2013). Using stable isotopes as markers of differences in foraging arenas, Ogonowski et al. (2013) found that $M$. salemaai (Audzijonytè \& Väinölä, 2005) exhibited isotope differences within the population. They concluded that a portion of the population was migratory, occupying the pelagic environment at night (presumably feeding on zooplankton), while remaining individuals were epibenthic day and night, feeding on detritus and benthic invertebrates. Consequently, observations of epibenthic mysids at night in North America (Morgan, 1980; Bowers, 1988) may also reflect fixed resident and migrant populations in Mysis.

In this study, we first determined whether Mysis exhibit partial DVM in Lake Champlain, USA, by sampling benthic and pelagic habitats at night. We then explored support for three hypotheses to explain partial DVM. Decision to migrate is associated with (1) the asset protection principle whereby reproductive status determines migration similar to observations in Lake Tahoe (Morgan, 1980); (2) body condition as measured by carbon to nitrogen ratio $(\mathrm{C}: \mathrm{N})$ as an estimate of lipid content, similar to what has been found in other partially migrating animals (Brodersen et al., 2008; Chapman et al., 2012); and 3) distinct population polymorphisms/ecotypes similar to M. salemaai in the Baltic Sea (Ogonowski et al., 2013). The hypotheses were explored using data on demographics, foraging habitat history (stable isotopes) and body condition ( $\mathrm{C}: \mathrm{N}$ ratios) of benthic and pelagic Mysis caught at night.

\section{Methods}

Study area

Mysis were sampled at three sites in Lake Champlain, USA (Fig. 1): Split Rock (SR; 44 $16^{\prime} 972^{\prime \prime} \mathrm{N}$,

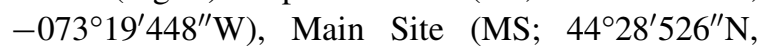
$\left.-073^{\circ} 18^{\prime} 241^{\prime \prime} \mathrm{W}\right)$, and Cumberland Head $(\mathrm{CH}$; $\left.44^{\circ} 38^{\prime} 462^{\prime \prime} \mathrm{N},-073^{\circ} 22^{\prime} 926^{\prime \prime} \mathrm{W}\right)$. The primary physical difference among sites was depth; SR was the 


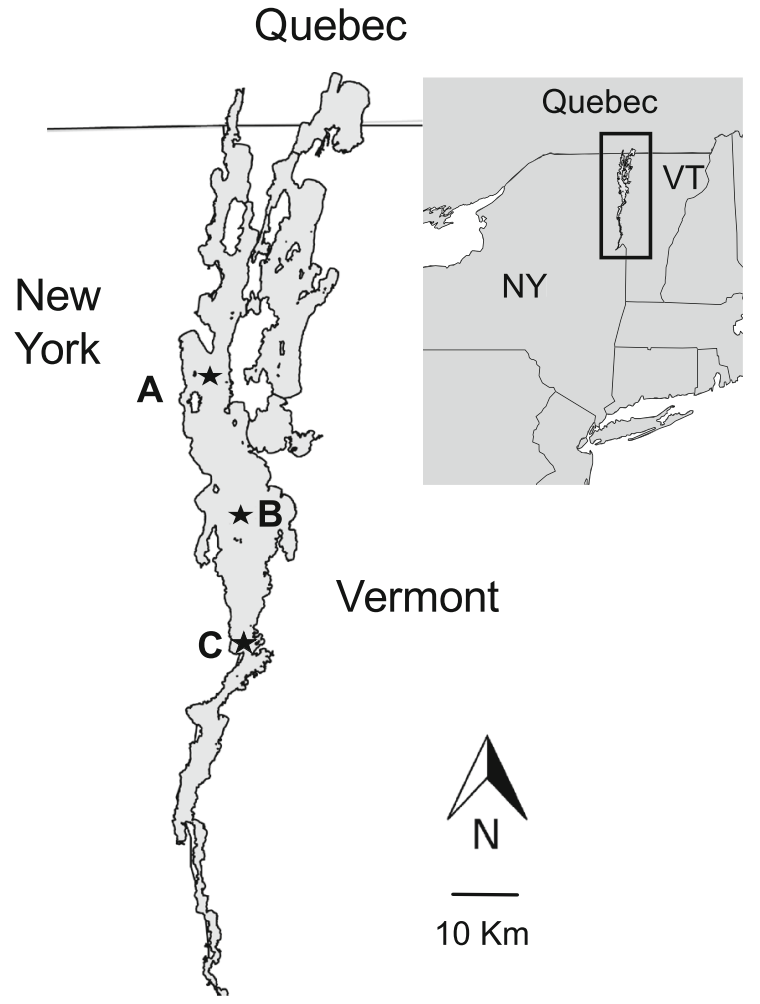

Fig. 1 Cumberland Head $(A)$, main site $(B)$, and Split Rock (C) sampling sites for Mysis collections in Lake Champlain, November 2013

deepest $(\approx 120 \mathrm{~m})$ followed by MS $(\approx 100 \mathrm{~m})$ and $\mathrm{CH}(\approx 70 \mathrm{~m})$.

\section{Sampling}

Mysis were sampled on several occasions during November 2013 to acquire average isotope composition and distribution for the month. Samples were pooled across dates during analyses. Samples were collected starting $1 \mathrm{~h}$ after nautical twilight and continued through the night ( $\approx 18: 00-02: 30$ ) in early (4-Nov, only site MS and benthic Mysis from SR), middle (13- and 14-Nov, all sites), and late November (19- and 20-Nov, all sites). The order in which sites were sampled was rotated across dates to account for any bias of sampling time. Prior to sampling, a conductivity-temperature-depth probe was deployed to measure thermal profiles at each site. Water temperature was between 8 and $10^{\circ} \mathrm{C}$ with little or no stratification at all three sites on all sampling dates. Moon phase ranged from just after new moon on $4-\mathrm{Nov}$ (moon rise $=09: 44$ ) to almost full on $20-\mathrm{Nov}$ (moon rise $=20: 10$ ), with partly cloudy skies on all nights.

Pelagic Mysis were collected using a combination of oblique and discrete tows with a Tucker trawl (opening $=3.6 \mathrm{~m}^{2} ;$ mesh $=1000 \mu \mathrm{m} ; \operatorname{cod}$ end $=$ $250 \mu \mathrm{m})$ at water column depths $0-50 \mathrm{~m}$. Benthiccaught Mysis were collected using an epibenthic sled (opening $=0.1 \mathrm{~m}^{2} ;$ mesh $=1000 \mu \mathrm{m} ; \operatorname{cod}$ end $=$ $250 \mu \mathrm{m}$ ) and represent only individuals within $\approx 0.5 \mathrm{~m}$ from the bottom.

Epibenthic transects were approximately $0.5 \mathrm{~km}$, while Tucker trawl transects were approximately $1.5 \mathrm{~km}$ to ensure sufficient numbers of pelagic-caught Mysis. No catch per unit effort was measured. Benthicand pelagic-caught samples from each site were placed in separate coolers filled with chilled lake water for transport to the laboratory. Within $10 \mathrm{~h}$ of collection, a target of 100 individual Mysis were haphazardly chosen from each date-site-habitat event, measured to the nearest $\mathrm{mm}$ from the tip of the rostrum to the base of telson, assessed for embryos or eggs, and individually frozen at $-20^{\circ} \mathrm{C}$ in $2-\mathrm{ml}$ centrifuge tubes.

Partial migration is defined as any population with migratory dimorphism (Chapman et al., 2011). Previous studies of Mysis have suggested that all or the vast majority of individual Mysis migrate each night (Shea \& Makarewicz, 1989). Therefore, if Mysis were captured in night benthic sled tows, the sample site population was classified as partially migratory. Additionally, we set a target number of 100 Mysis per date-site-habitat sample, thereby reducing the likelihood that Mysis captured in the water column by chance during deployment and retrieval of the benthic sled would impact the sample.

The size of Mysis (max length 20-25 mm tip of rostrum to base of telson), abundance, and habitat (deep, open water) makes mark- recapture studies an impractical method to evaluate individual migration characteristics. We therefore used stable isotopes as markers to test for DVM differences among individuals. $\delta^{13} \mathrm{C}$ of consumers differs between benthic and pelagic habitats because of variable reliance on particulate organic matter which is generally low in ${ }^{13} \mathrm{C}$ (France, 1995; Peterson, 1999). $\delta^{15} \mathrm{~N}$ of consumers differs with prey trophic level (Post, 2002), and benthic diets presumably contain a different proportion of low and high trophic level foods than pelagic diets. Finally, C:N ratio varies with diet composition, and can be used as a metric of body 
condition (high ratio associated with high fat content; Post et al., 2007). Stable isotopes change slowly over time (McMahon et al., 2013) and, therefore differences between benthic- and pelagic-caught mysids would suggest a sustained difference in habitat use. Ogonowski et al. (2013) found these markers to differ between benthic- and pelagic-caught $M$. salemaai. We used $\delta{ }^{34} \mathrm{~S}$ as an additional marker because the water column can be enriched in ${ }^{34} \mathrm{~S}$ compared to lake sediments (Croisetiere et al., 2009).

Length-frequency histograms were used to assess population size structure. Ten non-gravid Mysis from the most common size range across all samples (13$16 \mathrm{~mm}$ ) were randomly chosen from each date-sitehabitat group for $\mathrm{C}: \mathrm{N}$ ratio and carbon and nitrogen stable isotope analyses. Whole dried individuals were milled into a fine powder using a mortar and pestle, and $0.75-0.85 \mathrm{mg}$ of the sample was transferred to 3.5- $\times 5-\mathrm{mm}$ tin capsules (Costech Analytical Technologies Inc). Using whole individuals provided sufficient material to run duplicate samples per individual of carbon and nitrogen to assess precision.

The non-gravid mysids (10 per site, date and habitat) were analyzed for both carbon and nitrogen isotopes at the University of Wyoming Stable Isotope Facility using continuous-flow settings on a Costech 4010 Elemental Analyzer coupled to a Thermo Delta Plus XP IRMS. Results are expressed in parts per thousand (\%o) and denoted as $\delta$ according to the equation:

$\delta X=\left[\left(\frac{R_{\text {sample }}}{R_{\text {standard }}}\right)-1\right] * 1000$

where $X$ is ${ }^{15} \mathrm{~N}$ or ${ }^{13} \mathrm{C}, \mathrm{R}$ is the corresponding ratio ${ }^{15} \mathrm{~N}:{ }^{14} \mathrm{~N}$ or ${ }^{13} \mathrm{C}:{ }^{12} \mathrm{C}$, and the standard was Vienna Pee Dee belemnite (VPDB) for carbon and atmospheric $\mathrm{N}_{2}$ for nitrogen. For quality control, 36-UWSIF- Glutamic 1, 39-UWSIF-Glutamic 2, and UWSIF01 Liver were used for measurement of standard quality assurance ( $n=2$ per 24 samples). The standard deviations for $\delta^{13} \mathrm{C}$ and $\delta^{15} \mathrm{~N}$ of 36-UWSIF- Glutamic 1 and 39 -UWSIF-Glutamic 2 were \pm 0.2 and $\pm 0.05 \%$, \pm 0.1 and $\pm 0.04 \%$, respectively, and the standard deviations of UWSIF01 Liver were $\pm 0.1 \%$ for both $\delta^{13} \mathrm{C}$ and $\delta^{15} \mathrm{~N}$. Standard deviations of duplicate samples were 0.04 for $\delta{ }^{15} \mathrm{~N}$ and $0.34 \%$ for $\delta{ }^{13} \mathrm{C}$. Any samples that failed or had unusually high or low levels of $\mathrm{C}$ or $\mathrm{N}$ as noted by the stable isotope facility were removed from analysis.
Sulfur stable isotope analyses were conducted on other individual mysids than those used for $\delta^{13} \mathrm{C}$ and $\delta^{15} \mathrm{~N}$ (five 13-16 mm non-gravid individuals per site, habitat, and date, except from Nov. 4 due to incomplete sampling of sites on that date). Analyses were done on an Elementar vario ISOTOPE cube interfaced to a SerCon 20-22 IRMS (Sercon Ltd., Cheshire, UK) continuous-flow isotope-ratio mass spectrometer at the University of California Davis stable isotope facility. To account for variation in analysis, IAEA S-1, S-2, and S-3 were used as standard reference materials throughout sample measurement. The overall standard deviation for $\delta{ }^{34} \mathrm{~S}$ was $0.18 \%$ for $\mathrm{S}-1$, $0.22 \%$ for S-2 and $0.14 \%$ for S-3.

\section{Statistical analysis}

Differences in the numbers of gravid females between habitats and sites were evaluated using Chi Square test of Association. Samples from each site and habitat were pooled across date, and analysis was conducted on the total values for each site-habitat replicate.

To test for differences in length among sites and habitats, two-way analysis of variance (ANOVA) was used with habitat, site, and their interaction as principal factors. To assess possible differences in mean $\delta^{13} \mathrm{C}$ and $\delta^{15} \mathrm{~N}$, we conducted a two-way analysis of covariance (ANCOVA) with habitat, site, and their interaction as principal factors and $\mathrm{C}: \mathrm{N}$ mass ratio and length as covariates. $\mathrm{C}: \mathrm{N}$ was used as a covariate because $\delta^{13} \mathrm{C}$ can be influenced by lipid content, and C:N correlates with lipids (Post et al., 2007), while size was used to account for any size-related changes in diet. To assess differences in C: $\mathrm{N}$ and $\delta^{34} \mathrm{~S}$ at each site, two-way ANCOVAs were used with the same principal factors, but only length was used as a covariate. All analyses were conducted using $\mathrm{R}$ version 3.1.1 (R Core Team 2015) using the FSA (Ogle, 2014) and car (Fox \& Weisburn, 2011) packages with $\alpha=0.05$ and adjusted with a Bonferroni correction for multiple comparisons.

\section{Results}

Evidence for partial migration

Mysis were collected on bottom at night at all sites, consistent with the definition of partial migration 
(Chapman et al., 2011). Our target sample of 100 individuals was generally achieved within the first two to three benthic sled tows suggesting that densities were fairly high, though exact catch per unit effort and density were not quantified.

Mysis length and gravid females

A total of 1496 Mysis were measured and assessed for gravidity. However, because only benthic individuals were sampled from SR on 4-Nov due to equipment issues, these samples were removed from further consideration leaving 1396 individuals in the analysis. Mysis length ranged from 6 to $23 \mathrm{~mm}$ with a mean $( \pm \mathrm{SD})$ of $13.9 \pm 3.0 \mathrm{~mm}(\mathrm{~S} 1)$. Benthic- and pelagiccaught Mysis had almost identical length ranges (6-22 and 6-23 mm, respectively). Benthic-caught Mysis, however, had a higher mean body length than pelagiccaught Mysis (ANOVA $F_{1,1390}=42.6, P<0.001$, mean difference $=1.1 \mathrm{~mm}$; Fig. 2). Mysis lengths also differed among sites (ANOVA $F_{2,1390}=41.5$, $P<0.001$; Fig. 2) and were driven in part by differences between benthic- and pelagic-caught Mysis increasing with site depth (Fig. 3). Our shallowest site, $\mathrm{CH}$, had similar mean lengths between benthic- and pelagic-caught individuals (difference $=-0.59 \mathrm{~mm}$ ), while the difference at our deepest site, SR, was $3.1 \mathrm{~mm}$. The variation among sites led to a significant habitat:site interaction (ANOVA $F_{2,1390}=42.8$, $P<0.001$ ).

The proportion of the sampled Mysis found to be gravid was higher in benthic samples than pelagiccaught samples (Fig. 4; Table 1; $\chi^{2} P<0.001$ ). Additionally, the proportion of gravid Mysis within our samples varied by site $\left(\chi^{2} P<0.001\right)$. Only 32 out of 200 of Mysis (8\%) sampled at $\mathrm{CH}$ were gravid, while 113 out of $623(18 \%)$ of those sampled at MS and 98 out of $373(26 \%)$ of those sampled at SR were gravid (Fig. 4). In addition, the difference between benthic-caught and pelagic-caught gravid females increased with site depth (Fig. 3).

Stable isotope analysis

Mysis $\delta^{13} \mathrm{C}$ and $\delta^{15} \mathrm{~N}$ varied by site but not by habitat (Fig. 2; Table 2). Further, C:N had a positive relationship with $\delta^{13} \mathrm{C}$ and was therefore a significant covariate for $\delta^{13} \mathrm{C}$, (Table 2; Post et al., 2007), but length did not have an impact on either Mysis $\delta^{13} \mathrm{C}$ or $\delta^{15} \mathrm{~N}$ composition. $\delta{ }^{34} \mathrm{~S}$ was not significantly different between habitats or sites (Fig. 2).

Overall, Mysis C:N was higher in benthic-caught individuals but did not vary among sites (Fig. 2; Table 2). Additionally, length was a significant covariate for $\mathrm{C}: \mathrm{N}$. The difference in $\mathrm{C}: \mathrm{N}$ between habitats was largest at SR, our deepest site, and smallest at $\mathrm{CH}$, our shallowest site (Fig. 3).

\section{Discussion}

Our results provide evidence that Lake Champlain Mysis exhibit partial DVM, adding to the list of systems where Mysis spp. have been observed on the bottom at night (Moen \& Langeland, 1989; Rudstam et al., 1989; Ogonowski et al., 2013). Despite no quantitative assessment, the proportion of Mysis remaining on the bottom at night in November appears substantial. In all cases, our target number of 100 Mysis was surpassed within three benthic sled tows, while a much larger sampling effort was required to collect sufficient numbers of pelagic specimens. The observed catch rates appear to indicate that benthic densities were at least comparable to pelagic densities in contrast to Lake Ontario where catches from nighttime benthic sled tows were negligible (Shea \& Makarewicz, 1989). Additionally, recent benthicpelagic collections at night in Lake Champlain across seasons confirm our observations (Stockwell, unpublished data).

The larger average size of benthic-caught Mysis compared to pelagic-caught Mysis at the two deeper sites may indicate that large individuals are less migratory than smaller ones. The difference in size could be due to size-selective predation in the water column that decreases the abundance of larger Mysis (e.g., Holliland et al., 2012). Alternatively, larger Mysis with sufficient energy reserves to forego energyrich zooplankton may remain on the bottom as a strategy to avoid predation risk. However, the observed size differences were driven in part by the lack of migration of larger gravid females, which were $4.4 \mathrm{~mm}$ longer on average than non-gravid Mysis. Gravid females constituted a higher proportion of the sampled populations in benthic versus pelagic habitats at the two deeper sites, which partially supports the asset protection hypothesis (Hypothesis 1; Clark, 1994). The relatively small effect size of the overall 
Fig. 2 Mean $( \pm 95 \% \mathrm{CI})$ $\delta^{34} \mathrm{~S}, \delta^{15} \mathrm{~N}, \delta^{13} \mathrm{C}$ composition, and $\mathrm{C}: \mathrm{N}$ mass ratio of non-gravid Mysis $13-16 \mathrm{~mm}$ in length, and mean $( \pm 95 \% \mathrm{CI})$ length of all Mysis measured ( $n=1396)$ from benthic (B) and pelagic (P) habitats from the three sites in November 2013
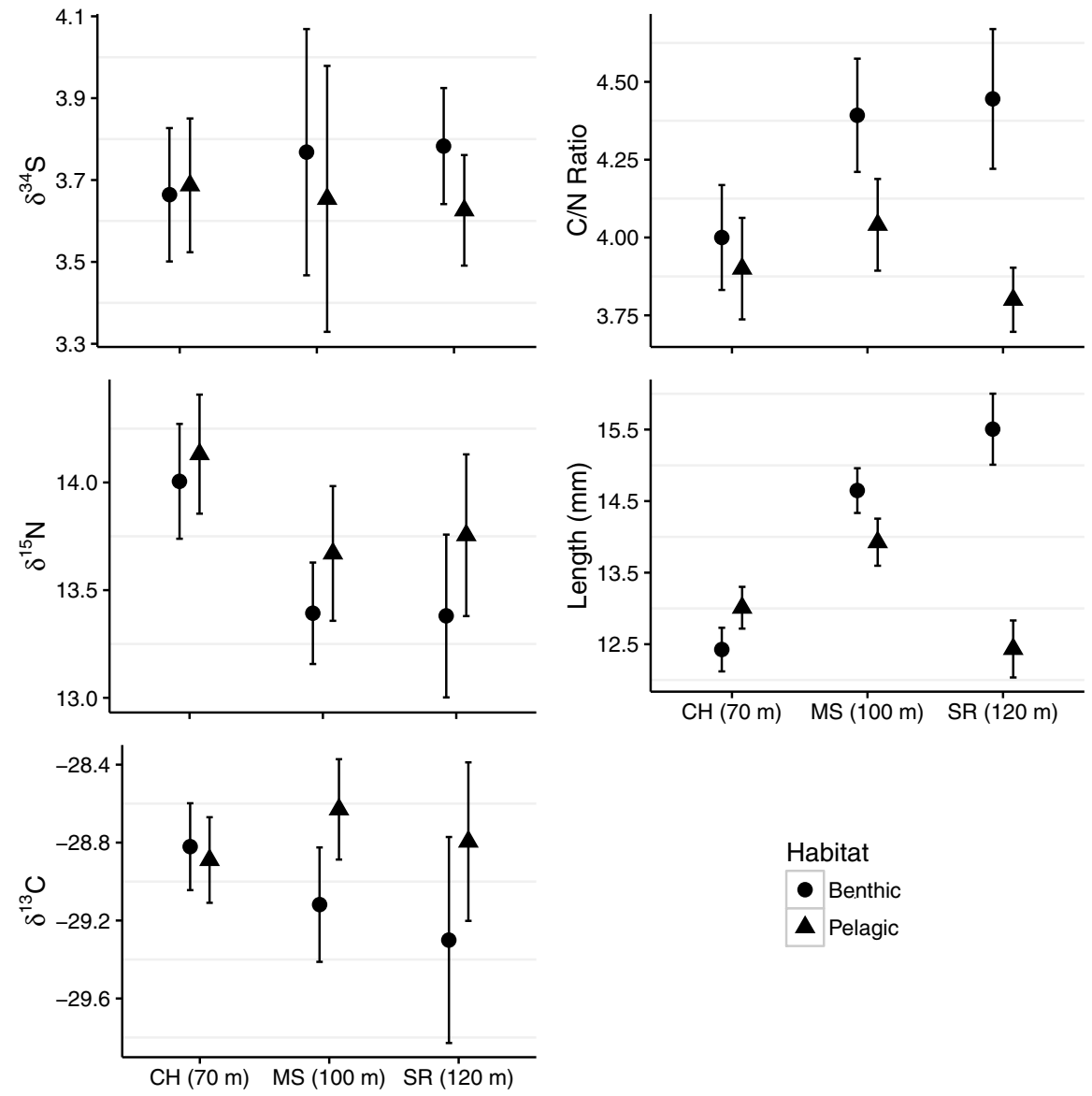

\section{Habitat}

- Benthic

$\Delta$ Pelagic

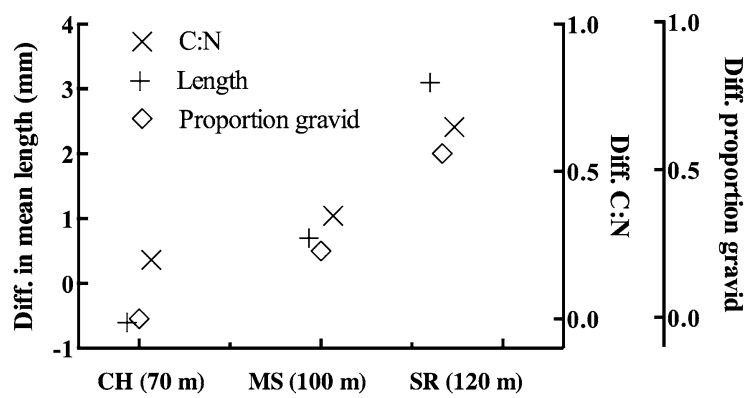

Fig. 3 Differences between Mysis mean length (mm), C:N, and proportion of gravid females by site depth $(\mathrm{CH} \approx 70 \mathrm{~m}$, MS $\approx 100 \mathrm{~m}, \mathrm{SR} \approx 120 \mathrm{~m}$ ) in Lake Champlain, November 2013

average length difference between benthic- and pelagic-caught individuals $(1 \mathrm{~mm})$, the size overlap between Mysis that migrate and those that remain on bottom, and observations of gravid females in pelagic samples, however, suggest that size and life stage differences cannot fully explain partial migration behavior.

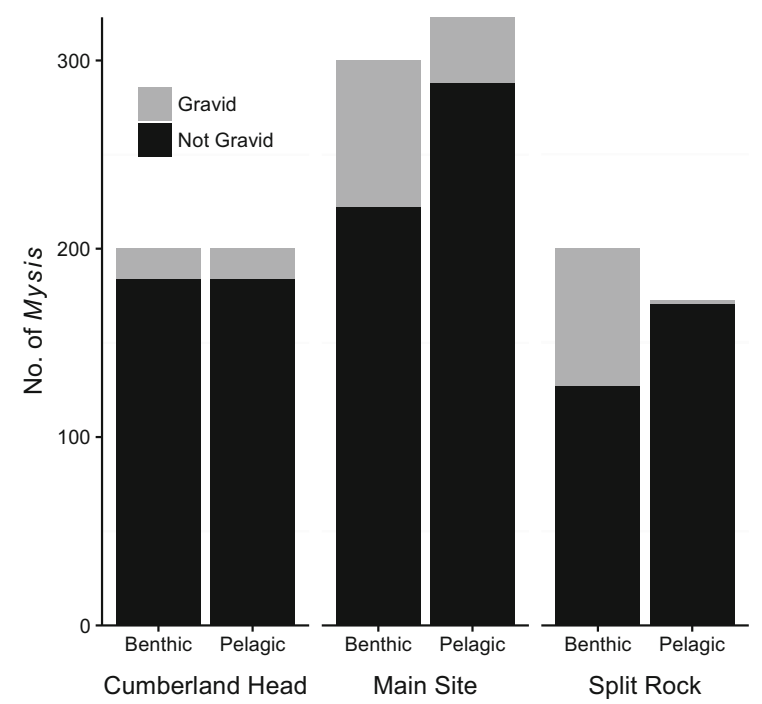

Fig. 4 Number of Mysis identified as gravid (gray) or nongravid (black) in benthic and pelagic habitats at each site in Lake Champlain, November 2013 
Table 1 Mean ( \pm SD) Mysis length (L), number gravid Mysis observed for $n$ individuals, and mean ( \pm SD) C:N of ten non-gravid 13-16 mm individuals over all dates, sites, and habitats in Lake Champlain in November 2013

\begin{tabular}{llllrr}
\hline Site & Habitat & $\mathrm{n}$ & Mean L $(\mathrm{mm})$ & No. gravid Mysis & Mean C:N \\
\hline SR & Benthic & 200 & $15.5 \pm 3.55$ & 73 & $4.45 \pm 0.48$ \\
& Pelagic & 173 & $12.4 \pm 2.66$ & 2 & $3.80 \pm 0.22$ \\
MS & Benthic & 300 & $14.6 \pm 2.75$ & 78 & $4.39 \pm 0.46$ \\
& Pelagic & 323 & $13.9 \pm 3.00$ & 35 & $4.04 \pm 0.37$ \\
CH & Benthic & 200 & $12.4 \pm 2.19$ & 16 & $4.00 \pm 0.35$ \\
& Pelagic & 200 & $13.0 \pm 2.09$ & 16 & $3.90 \pm 0.34$ \\
\hline
\end{tabular}

Table 2 Results of two-way ANCOVAs testing for differences in Lake Champlain Mysis isotopic composition and C:N ratios among non-gravid individuals caught in November 2013 from three different sites in benthic and pelagic habitats

\begin{tabular}{|c|c|c|c|c|c|c|c|c|c|}
\hline \multirow[t]{2}{*}{ Factors } & \multicolumn{3}{|c|}{$\delta^{13} \mathrm{C}$} & \multicolumn{2}{|l|}{$\delta^{15} \mathrm{~N}$} & \multicolumn{2}{|l|}{$\mathrm{C}: \mathrm{N}$} & \multicolumn{2}{|l|}{$\delta^{34} \mathrm{~S}$} \\
\hline & df & $F$ & $P$ & $F$ & $P$ & $F$ & $P$ & $F$ & $P$ \\
\hline Habitat & 1 & 3.83 & 0.053 & 4.61 & 0.033 & 29.92 & $<0.001 *$ & 1.10 & 0.298 \\
\hline Site & 2 & 6.89 & $0.001 *$ & 7.13 & $0.001 *$ & 3.42 & 0.036 & 0.01 & 0.989 \\
\hline Habitat:site & 2 & 1.86 & 0.160 & 0.45 & 0.637 & 4.50 & 0.013 & 0.40 & 0.671 \\
\hline $\mathrm{C}: \mathrm{N}$ & 1 & 145.85 & $<0.001 *$ & 0.45 & 0.503 & NA & NA & NA & NA \\
\hline Length & 1 & 0.36 & 0.550 & 0.02 & 0.899 & 7.11 & $0.009 *$ & 0.30 & 0.587 \\
\hline
\end{tabular}

$N A$ indicates variables that were not part of the analysis. $F$ values that were significant following a Bonferroni correction for multiple comparisons are denoted with asterisks

* Significant following Bonferroni correction

Notably, non-gravid benthic-caught individuals had an average $\mathrm{C}: \mathrm{N}$ ratio $9 \%$ higher than non-gravid pelagic-caught individuals at MS and $17 \%$ higher at SR, representing a potential difference in tissue lipid content of $2.5 \%$ at MS and $4.6 \%$ at SR based on dry mass (Post et al., 2007). Mysis with higher lipid content were captured on the bottom where predation risk is likely lower (Harrington et al., 2015), while Mysis with lower lipid content (lower nutritional status) may migrate to pelagic waters to access higher density and presumably more energy-rich prey, but at a presumably increased risk of predation. However, the difference in lipid content between benthic-caught and pelagic-caught Mysis at $\mathrm{CH}$ was less than $1 \%$, again suggesting other factors likely contribute to partial DVM. Nonetheless, the differences in C:N at two out of three sites support that condition may be one factor in migration choice (Hypothesis 2).

Contrary to results from Ogonowski et al. (2013), we found no differences in $\delta^{15} \mathrm{~N}$ and $\delta^{13} \mathrm{C}$ between benthic- and pelagic-caught Mysis. Diet differences, such as those expected between epibenthic Mysis with no DVM and vertically migrating pelagic individuals, may not necessarily result in different isotopic signatures (c.f. Phillips \& Gregg, 2003; Sweeting et al., 2005; Brett, 2014). Consequently, the absence of significant differences in isotope composition in the present study precludes us from rejecting distinct ecotypes of Mysis (Hypothesis 3). However, because length and $\mathrm{C}: \mathrm{N}$ differed between habitats, partial migrations are likely true partial migrations and not simply the result of continuous re-distributions of the Mysis population in the water column throughout the night. Nonetheless, to conclusively test Hypothesis 3 that Mysis partial migration is related to fixed population polymorphism, we recommend that future studies use additional markers such as fatty acids (Brett, 2014) and Mysis stomach content analyses (O’Malley \& Bunnell, 2014).

Mysis exhibited partial migration at all sites. The effect size of demographics and $\mathrm{C}: \mathrm{N}$ between benthicand pelagic-caught Mysis, however, differed among 
sites and increased with depth. In Lake Superior, isotope composition of Mysis changed with depth and was attributed to decomposition of detritus as it sinks to the bottom (Sierszen et al., 2011). The depths of our study sites (70-120 m), however, were shallower than assessed by Sierszen et al. (2011; 120-300 m), and we saw no large differences in Mysis isotope composition with depth. Thus, the differences in Mysis demographics and $\mathrm{C}: \mathrm{N}$ by depth found in the present study were more likely associated with Mysis feeding or migration behavior among sites than depth-mediated isotope changes in detritus.

Interpretation of our results is limited to the month of November when stratification in Lake Champlain is negligible. At this time, the distributions of predators and prey are presumably more vertically homogenous than during stratified periods, likely limiting the energetic advantage near the surface and decreasing the presumed predator refuge near the bottom. Pelagic productivity, thermal stratification, and presence of predators are proximate factors known to impact the depth to which Mysis migrate at night during May through September (Boscarino et al., 2007, 2009b). However, Mysis continue to migrate even when stratification breaks down and may even migrate closer to the surface in autumn than in the spring (Beeton, 1960; Ahrenstorff et al., 2011). Therefore, evaluating Mysis distribution and condition during other months when stratification and predator densities are more distinct may help further elucidate the drivers of partial DVM. However, the presence of two alternative migration strategies in November implies that bimodal behaviors do exist in Mysis at certain times of the year. Surveys of Lake Champlain suggest partial that DVM occurs year round (Stockwell, unpublished data).

Research identifying individual differences in the migration traits of invertebrates, and specifically in vertically migrating invertebrates, is underrepresented in aquatic ecology research. To the best our knowledge, our work and that of Ogonowski et al. (2013) are the only studies that have directly identified and assessed the benthic component of partial migration behavior of Mysis spp. While other studies have discussed partial DVM (Morgan, 1980; Bowers, 1988; Rudstam et al., 1989), the predominant focus of Mysis DVM research continues to be on individuals that have migrated into the water column. Our results partially support both the body condition and the asset protection hypotheses as explanations of partial DVM. However, neither hypothesis was supported at all sites. Despite inconsistencies among sites, our findings suggest that partial migration may be a nonrandom process. Non-random partial DVM of Mysis adds complexity to our understanding of DVM and necessitates more detailed description of benthic and pelagic distributions of Mysis to determine when and why individuals migrate. We propose that future studies of vertically migrating organisms account for potential partial migration by expanding sampling techniques to better represent non-migratory individuals (e.g., Shea \& Makarewicz, 1989; Stockwell et al., 2010). Selective sampling techniques that do not account for the full distribution of the target species could bias abundance estimates (e.g., Stockwell et al., 2006). The key role Mysis play in food webs (e.g., Ellis et al., 2011; Gamble et al., 2011; Isaac et al., 2012) makes understanding impacts of Mysis on both benthic and pelagic communities essential for estimates of energy flow and connectivity in food web and ecosystem models (Kitchell et al., 2000; Stewart et al., 2010; Bunnell et al., 2011).

Acknowledgments We thank Mike Sierszen and Brian O'Malley for thoughtful discussions about Mysis ecology and anonymous reviewers for their constructive input during earlier drafts. Additionally, we thank Captain Steve Cluett and Deckhand Suz Ball of the RV Melosira for their expertise in the field, and Rachael DeWitt, Jake Calvitti, and Carey Phalen for their help with collection and processing of samples. We also express our gratitude to Andrea Lini for the use of his laboratory for sample preparation. Finally, we thank the University of Vermont's James Marsh Professor-at-Large program for providing the financial support to $\mathrm{SH}$ and the collection of samples.

Open Access This article is distributed under the terms of the Creative Commons Attribution 4.0 International License (http:// creativecommons.org/licenses/by/4.0/), which permits unrestricted use, distribution, and reproduction in any medium, provided you give appropriate credit to the original author(s) and the source, provide a link to the Creative Commons license, and indicate if changes were made.

\section{References}

Ahrenstorff, T. D., T. R. Hrabik, J. D. Stockwell, D. L. Yule \& G. G. Sass, 2011. Seasonally dynamic diel vertical migrations of Mysis diluviana, coregonine fishes, and siscowet lake trout in the pelagia of Western Lake Superior. 
Transactions of the American Fisheries Society 140: 1504-1520.

Audzijonytè, A. \& R. Väinölä, 2005. Diversity and distributions of circumpolar fresh- and brackish-water Mysis (Crustacea: Mysida): descriptions of $M$. relicta Lovén, 1862, $M$. salemaai n. sp., M. segerstralei n. sp. and M. diluviana n. sp., based on molecular and morphological characters. Hydrobiologia 544: 89-141.

Beeton, A., 1960. The vertical migration of Mysis relicta in Lakes Huron and Michigan. Journal of the Fisheries Board of Canada 17: 517-539.

Beeton, A. \& J. Bowers, 1982. Vertical migration of Mysis relicta Loven. Hydrobiologia 93: 53-61.

Boscarino, B. T., L. G. Rudstam, S. Mata, G. Gal, O. E. Johannsson, O. Lr \& E. L. Mills, 2007. The effects of temperature and predator - prey interactions on the migration behavior and vertical distribution of Mysis relicta. Limnology and Oceanography 52: 1599-1613.

Boscarino, B. T., L. G. Rudstam, J. Eillenberger \& R. O'Gorman, 2009a. Importance of light, temperature, zooplankton and fish in predicting the nighttime vertical distribution of Mysis diluviana. Aquatic Biology 5: 263-279.

Boscarino, B. T., L. G. Rudstam, E. R. Loew \& E. L. Mills, 2009b. Predicting the vertical distribution of the opossum shrimp, Mysis relicta, in Lake Ontario: a test of laboratorybased light preferences. Canadian Journal of Fisheries and Aquatic Sciences 66: 101-113.

Boscarino, B. T., L. G. Rudstam, J. Tirabassi, J. Janssen \& E. R. Loew, 2010. Light effects on alewife-mysid interactions in Lake Ontario: a combined sensory physiology, behavioral, and spatial approach. Limnology and Oceanography 55: 2061-2072.

Bowers, J., 1988. Diel vertical migration of the Opossum Shrimp Mysis relicta in Lake Superior: observations and sampling from the Johnson-Sea-Link II submersible. Bulletin of Marine Science 43: 730-738.

Brett, M. T., 2014. Resource polygon geometry predicts Bayesian stable isotope mixing model bias. Marine Ecology Progress Series 514: 1-12.

Brodersen, J., P. Nilsson, L.-A. Hansson, C. Skov \& C. Bronmark, 2008. Condition-dependent individual decisionmaking determines cyprinid partial migration. Ecology 89: 1195-1200.

Brodersen, J., A. Nicolle, P. A. Nilsson, C. Skov, C. Brönmark \& L.-A. Hansson, 2011. Interplay between temperature, fish partial migration and trophic dynamics. Oikos 120: 1838-1846.

Bunnell, D. B., B. M. Davis, D. M. Warner, M. A. Chriscinske \& E. F. Roseman, 2011. Planktivory in the changing Lake Huron zooplankton community: Bythotrephes consumption exceeds that of Mysis and fish. Freshwater Biology 56: 1281-1296.

Carpenter, G., E. Mansey \& N. Watson, 1974. Abundance and life history of Mysis relicta in St. Lawrence. Journal of The fisheries Research Board of Canada 31: 319-325.

Chapman, B. B., C. Brönmark, J.-Å. Nilsson \& L.-A. Hansson, 2011. The ecology and evolution of partial migration. Oikos 120: 1764-1775.

Chapman, B. B., C. Skov, K. Hulthén, J. Brodersen, P. A. Nilsson, L. A. Hansson \& C. Brönmark, 2012. Partial migration in fishes: definitions, methodologies and taxonomic distribution. Journal of fish biology 81: 479-499.

Clark, C., 1994. Anitpredator behaior and the asset-protection principle. Behavioral Ecology 5: 159-170.

Clark, C. W. \& D. A. Levy, 1988. Diel vertical migrations by juvenile sockeye salmon and the antipredation window. American Naturalist 131: 271-290.

Croisetiere, L., L. Hare, A. Tessier \& G. Cabana, 2009. Sulphur stable isotopes can distinguish trophic dependence on sediments and plankton in boreal lakes. Freshwater Biology 54: 1006-1015.

Ellis, B. K., J. A. Stanford, D. Goodman, C. P. Stafford, D. L. Gustafson, D. A. Beauchamp, D. W. Chess, J. A. Craft, M. A. Deleray \& B. S. Hansen, 2011. Long-term effects of a trophic cascade in a large lake ecosystem. Proceedings of the National Academy of Sciences of the United States of America 108: 1070-1075.

Fox, J., \& S. Weisburn, 2011. An R Companion to Applied Regression. http://socserv.socsci.mcmaster.ca/jfox/Books/ Companion.

France, R., 1995. Carbon-13 enrichment in benthic compared to planktonic algae: foodweb implications. Marine ecology progress series. Oldendorf 124: 307-312.

Gamble, A. E., T. R. Hrabik, J. D. Stockwell \& D. L. Yule, 2011. Trophic connections in Lake Superior Part I: the offshore fish community. Journal of Great Lakes Research 37: 541-549.

Harrington, K., T. R. Hrabik \& A. Mensinger, 2015. Visual sensitivity of deepwater fishes in Lake Superior. Plos One 10: e0116173.

Hays, G. C., 2003. A review of the adaptive significance and ecosystem consequences of zooplankton diel vertical migrations. Hydrobiologia 503: 163-170.

Holliland, P. B., I. Ahlbeck, E. Westlund \& S. Hansson, 2012. Ontogenetic and seasonal changes in diel vertical migration amplitude of the calanoid copepods Eurytemora affinis and Acartia spp. in a coastal area of the northern Baltic proper. Journal of Plankton Research 34: 298-307.

Isaac, E. J., T. R. Hrabik, J. D. Stockwell \& A. E. Gamble, 2012. Prey selection by the Lake Superior fish community. Journal of Great Lakes Research 38: 326-335.

Johannsson, O. E., M. F. Leggett, L. G. Rudstam, M. R. Servos, A. M. Mohammadian, G. Gal, R. M. Dermott \& R. H. Hesslein, 2001. Diet of Mysis relicta in Lake Ontario as revealed by stable isotope and gut content analysis. Canadian Journal of Fisheries and Aquatic Sciences 58: 1975-1986.

Kelly, J. R., P. M. Yurista, S. E. Miller, A. C. Cotter, T. C. Corry, J. S. Scharold, M. E. Siersen, E. J. Isaac \& J. D. Stockwell, 2011. Challenges to lake superior's condition, assessment, and management: a few observations across a generation of change. Aquatic Ecosystem Health and Management 14: 332-344.

Kitchell, J. F., S. P. Cox, C. J. Harvey, T. B. Johnson, D. M. Mason, K. K. Schoen, K. Aydin, C. Bronte, M. Ebener, M. Hansen, M. Hoff, S. Schram, D. Schreiner \& C. J. Walters, 2000. Sustainability of the Lake Superior fish community: interactions in a food web context. Ecosystems 3: 545-560.

Lampert, W., 1989. The adaptive significance of diel vertical migration of zooplankton. Functional Ecology 3: 21-27. 
Longhurst, A. \& W. G. Harrison, 1988. Vertical nitrogen flux from the oceanic photic zone by diel migrant zooplankton and nekton. Deep Sea Research 35: 881-889.

Loose, C. \& P. Dawidowicz, 1994. Trade-offs in diel vertical migration by zooplankton: the costs of predator avoidance. Ecology 75: 2255-2263.

Lundberg, P., 1987. Partial bird migration and evolutionarily stable strategies. Journal of Theoretical Biology 125: 351-360.

Lundberg, P., 1988. The evolution of partial migration in birds. Trends in ecology \& evolution 3: 172-175.

McMahon, K. W., L. Ling Hamady \& S. R. Thorrold, 2013. A review of ecogeochemistry approaches to estimating movements of marine animals. Limnology and Oceanography 58: 697-714.

Mehner, T., 2012. Diel vertical migration of freshwater fishes proximate triggers, ultimate causes and research perspectives. Freshwater Biology 57: 1342-1359.

Mehner, T. \& P. Kasprzak, 2011. Partial diel vertical migrations in pelagic fish. The Journal of animal ecology 80: 761-770.

Moen, V. \& A. Langeland, 1989. Diurnal vertical and seasonal horizontal distribution patterns of Mysis relicta in a large Norwegian lake. Journal of Plankton Research Oxford University Press 11: 729-745.

Morgan, M., 1980. Life history characteristics of two introduced populations of Mysis relicta. Ecology 61: 551-561.

O’Malley, B. P. \& D. B. Bunnell, 2014. Diet of Mysis diluviana reveals seasonal patterns of omnivory and consumption of invasive species in offshore Lake Michigan. Journal of Plankton Research 36: 989-1002.

Ogle, D. H., 2014. FSA: Fisheries Stock Analysis.

Ogonowski, M., J. Duberg, S. Hansson \& E. Gorokhova, 2013. Behavioral, ecological and genetic differentiation in an open environment - a study of a mysid population in the Baltic Sea. Plos One 8: e57210.

Oliver, S. K., D. K. Branstrator, T. R. Hrabik, S. J. Guildford \& R. E. Hecky, 2014. Nutrient excretion by crustacean zooplankton in the deep chlorophyll layer of Lake Superior. Canadian Journal of Fisheries and Aquatic Sciences 72: 390-399.

Pearre, S., 2003. Eat and run? The hunger/satiation hypothesis in vertical migration: history, evidence and consequences. Biological reviews of the Cambridge Philosophical Society 78: 1-79.

Peterson, B. J., 1999. Stable isotopes as tracers of organic matter input and transfer in benthic food webs: a review. Acta Oecologica 20: 479-487.

Phillips, D. L. \& J. W. Gregg, 2003. Source partitioning using stable isotopes: coping with too many sources. Oecologia 136: 261-269.
Post, D. M., 2002. Using stable isotopes to estimate trophic position: models, methods, and assumptions. Ecology 83: 703-718.

Post, D. M., C. A. Layman, D. A. Arrington, G. Takimoto, J. Quattrochi \& C. G. Montaña, 2007. Getting to the fat of the matter: models, methods and assumptions for dealing with lipids in stable isotope analyses. Oecologia 152: 179-189.

R Core Team., 2015. R: A Language and Enviornment for Satistical Computing. R Foundation for Satisical Computing, Vienna. http://www.r-project.org/.

Rudstam, L. G., K. Danielsson, S. Hansson \& S. Johansson, 1989. Diel vertical migration and feeding patterns of Mysis mixta (Crustacea, Mysidacea) in the Baltic Sea. Marine Biology 101: 43-52.

Schnetzer, A. \& D. Steinberg, 2002. Active transport of particulate organic carbon and nitrogen by vertically migrating zooplankton in the Sargasso Sea. Marine Ecology Progress Series 234: 71-84.

Shea, M. A. \& J. C. Makarewicz, 1989. Production, biomass, and trophic interactions of Mysis relicta in Lake Ontario. Journal of Great Lakes Research 15: 223-232.

Sierszen, M., J. Kelly, T. Corry, J. Scharold \& P. Yurista, 2011. Benthic and pelagic contributions to Mysis nutrition across Lake Superior. Canadian Journal of Fisheries and Aquatic Sciences 68: 1051-1063.

Sierszen, M. E., T. R. Hrabik, J. D. Stockwell, A. M. Cotter, J. C. Hoffman \& D. L. Yule, 2014. Depth gradients in foodweb processes linking habitats in large lakes: Lake Superior as an exemplar ecosystem. Freshwater Biology 59: 2122-2136.

Stewart, T., R. O’Gorman, W. G. Sprules \& B. Lantry, 2010. The bioenergetic consequences of invasive-induced food web disruption to Lake Ontario alewives. North American Journal of Fisheries Management 30: 1485-1504.

Stockwell, J. D., D. Yule, O. Gorman, E. J. Isaac \& S. A. Moore, 2006. Evaluation of bottom trawls as compared to acoustics to assess adult lake herring (Coregonus artedi) abundance in Lake Superior. Journal of Great Lakes Research 32: 280-292.

Stockwell, J. D., T. R. Hrabik, O. P. Jensen, D. L. Yule \& M. Balge, 2010. Empirical evaluation of predator-driven diel vertical migration in Lake Superior. Canadian Journal of Fisheries and Aquatic Sciences 67: 473-485.

Sweeting, C., S. Jennings \& N. Polunin, 2005. Variance in isotopic signatures as a descriptor of tissue turnover and degree of omnivory. Functional Ecology 19: 777-784. 